\title{
An epidemiological study of road traffic accident cases admitted in a tertiary care centre of Uttar Pradesh
}

\author{
Verma P. ${ }^{1 *}$, Gupta S. ${ }^{2}$, Singh G. ${ }^{3}$ \\ DOI: https://doi.org/10.17511/ijphr.2015.i4.04
}

1* Preeti Verma, Assistant Professor, Department of Orthopedics, Saraswathi Institute of Medical Sciences, Hapur, Uttar Pradesh, India.

2 S C Gupta, Professor, Department of Community Medicine, Saraswathi Institute of Medical Sciences, Hapur, Uttar Pradesh, India.

3 Gagan Singh, JR, Department of orthopedics, Saraswathi Institute of Medical Sciences, Hapur, Uttar Pradesh, India.

Introduction: Worldwide about 1.3 million people die each year as a result of road traffic accidents and are the leading cause of death among young people, aged 15-29 years. Nearly half $(46 \%)$ of those dying on the world's roads are vulnerable road users (pedestrians, cyclists and motorcyclist. Objectives: (1) To study the sociodemographic profile of road traffic accident (RTA) cases (2) To know the type of road users and the counterpart involved in the road traffic accidents. Methodology: A hospital based cross-sectional study, conducted at Emergency Department\& Hospital of S.N Medical College, Agra. By using systematic sampling technique, a total of 425 RTA cases were registered for the study. Cases or their attendant were interviewed based on a semi structured questionnaire. Results: Out of 425 RTA cases majority were Hindus (90.6\%), males $(89.6 \%)$, from urban areas $(72 \%)$, married $(65.8 \%)$ and illiterate $(62.8 \%)$. Maximum belonged to $16-30$ years age group $(40.0 \%)$ and laborers $(42.3 \%)$ while mostly $(82.8 \%)$ were from upper- lower social class. Of 425 cases, $37.6 \%$ were pedestrians and $33.2 \%$ were hit by motorized two wheeler. Conclusion: Majority of the RTA cases are in the economically productive age group and are married, hence their hospitalization or disability places a huge economic burden on the family.

Keywords: Emergency Department, Road Traffic Accidents, Sociodemographic Profile, Type of Road Users, Tertiary Care Centre

\section{Corresponding Author}

Preeti Verma, Assistant Professor, Department of Orthopedics, Saraswathi Institute of Medical Sciences, Hapur, Uttar Pradesh, India. Email: dr.preetivermakgmc2002@gmail.com

\section{How to Cite this Article}

Verma P, Gupta SC, Singh G. An epidemiological study of road traffic accident cases admitted in a tertiary care centre of Uttar Pradesh. Public Health Rev Int J Public Health Res. 2015;2(4):43-48. Available From https://publichealth.medresearch.in/index.php/ijphr/ article/view/18
To Browse

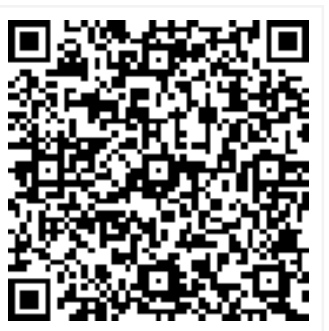

Manuscript Received 2015-10-28

Conflict of Interest No
Review Round 1 2015-11-10

Funding Nil

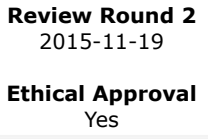

Review Round 3

Plagiarism X-checker $8 \%$
Accepted 2015-12-03

(C) 2015 by Preeti Verma, S C Gupta, Gagan Singh and Published by Siddharth Health Research and Social Welfare Society. This is an Open Access article licensed under a Creative Commons Attribution 4.0 International License https://creativecommons.org/licenses/by/4.0/ unported [CC BY 4.0]. 


\section{Introduction}

Spectacular advances in health and health related sciences has brought down the morbidity and mortality due to communicable diseases and has resulted in longevity of people. At the same time, globalization has improved the socio-economic status resulting in more use of vehicles and the travel, further resulting in increased number of RTAs. Thus the entire spectrum of non communicable diseases and accidents has come to the forefront of health care delivery system.

According to WHO, deaths from road traffic accidents account for around $25 \%$ of all deaths from injury. The total number of road traffic deaths and injuries worldwide is forecast to rise by some $65 \%$ between 2000 and 2020. About 1.3 million people die each year as a result of road traffic accidents and are the leading cause of death among young people, aged $15-29$ years.

Over $90 \%$ of the world's fatalities on the roads occur in low-income and middle-income countries, even though these countries have less than half of the world's vehicles. Nearly half $(46 \%)$ of those dying on the world's roads are vulnerable road users (pedestrians, cyclists and motorcyclist. Without action, the road traffic accidents are predicted to result in the deaths of around 1.9 million people annually by 2020 [1].

'Road accidents' cases in India have marginally increased by $0.7 \%$ during 2013 as compared to 2012 , while casualties decreased by $1.2 \%$. A total of $4,75,625$ traffic accidents cases were reported during the year 2013 comprising 4,43,001 RTA cases and these accidents accounted for $1,37,423$ deaths due to RTA.

The analysis of road accident deaths by various mode of transport revealed that 34,187 persons $(24.9 \%)$ were riding on two-wheelers, 24,081 $(17.5 \%)$ were occupants of truck/lorry, 14,803 $(10.8 \%)$ were travelling in car and $12,055(8.8 \%)$ were killed while travelling in buses and most of the victims of accidents deaths were under age group of 15 to 44 years. 66 deaths per day were by truck/ lorry and 94 deaths were by two wheelers [2].

\section{Aim and Objectives}

01 . To study the sociodemographic profile of RTA cases

02. To know the type of road users and the counterpart involved in the road traffic accidents

\section{Material and Methods}

The present study is a hospital based cross sectional study, conducted from April 2012 to March 2013 among cases admitted in Emergency Department or Hospital of SN Medical College, Agra due to road traffic accidents. The ethical clearance was given by ethical committee of S.N. Medical College, Agra. By using systematic sampling technique, a total of 425 RTA cases were registered for the study. The cases or their attendants after obtaining informed and written consent were interviewed by using a semi structured questionnaire. The Road traffic accidents cases were operationally defined as "injuries occurring on road involving two or more objects, one of which was any kind of moving object" [3].

\section{Exclusion Criteria}

01. Cases / relatives who did not give written consent to participate in the study.

02. Cases who were admitted for a very short duration were also excluded from the study.

\section{Sample Size}

The sample size of the study group was calculated by using the formula given below-

(N) $=\mathrm{Z} 2 \mathrm{a} \% \mathrm{pq} / \mathrm{D} 2$

Where-

$=$ Standard Normal variate at level of significance $=$ 1.96

P (Proportion ) $=30 \%$ (A study by G. Gururaj, 2008 revealed that $30 \%$ of admission of the emergency rooms are due to road traffic injuries which has been taken as the criteria) [4].

$Q=100-p=70$

$D($ Decision error $)=15 \%$ of proportion.

The sample size came out to be 398 . Considering a dropout rate of $7 \%$, the sample size was increased to 425 .

\section{Methodology}

It was found out that in ED \& Hospital of S.N. Medical College, Agra, the number of RTA cases admitted was approximately 1500 per annum. In order to achieve the desired sample size $(n=425)$, three visits on alternate days of week were made and all the cases admitted on that day were registered for the study. 
For first and third weeks of every month, the days selected were Monday, Wednesday and Friday while for second and fourth weeks of the month, the cases were interviewed on Tuesday, Thursday, Saturday and Sunday.

Data processing and statistical analysis: Statistical analysis was done using SPSS version 20.0.The data were summarized using percentages and frequency. Significant difference was determined by using chi-square test and standard error of difference between two proportions ( $Z$ test) and the difference was accepted significant at $p$ value $<0.05$.

\section{Result}

Table 1 shows the distribution of RTA cases according to the different age and sex groups. It was found that majority cases were males $(89.6 \%)$ and females were only $10.4 \%$. Overall age distribution shows that maximum cases $(40.0 \%)$ belonged to $16-30$ years age group followed by 31 45 years age group $(25.8 \%)$ and only $6.1 \%$ cases were of $<15$ years age. This age wise variation was statistically significant $(p<0.05)$. Among males distribution was similar to overall distribution, being maximum in 16-30years age group, followed by 31 45 years $(42.3 \% \& 27.6 \%$ respectively). Thus, in males majority (69.9\%) cases occurred in $16-45$ years age group which is the productive age. On the contrary in females, maximum RTA cases (34.1\%) occurred in 45-60 years age group followed by $22.7 \%$ cases in $<15$ years age group. Statistically there is highly significant difference between sex variation in various age groups (chi square test) and among different age groups all the individual age groups ( $Z$ test) except above 60 yrs age (table 1 ).

Table-1: Age and sex wise distribution of RTA cases.

\begin{tabular}{|l|l|l|l|l|}
\hline \multirow{2}{*}{ Age group* } & \multicolumn{3}{|c|}{ Road traffic accident cases } & \multirow{2}{*}{ Z value } \\
\cline { 2 - 4 } & Male & Female & Total & \\
\hline$<15$ yrs & $16(4.2)$ & $10(22.7)$ & $26(6.1)$ & 2.89 \\
\hline $16-30 \mathrm{yrs}$ & $161(42.3)$ & $9(20.5)$ & $170(40)$ & 3.31 \\
\hline $31-45 \mathrm{yrs}$ & $105(27.6)$ & $5(11.4)$ & $110(25.8)$ & 3.07 \\
\hline $46-60 \mathrm{yrs}$ & $63(16.5)$ & $15(34.1)$ & $78(18.3)$ & 2.37 \\
\hline$>60 \mathrm{yrs}$ & $36(9.4)$ & $5(11.4)$ & $41(9.6)$ & 0.4 \\
\hline Total & $381(89.6)$ & $44(10.4)$ & $425(100.0)$ & \\
\hline $\mathrm{X} 2=37.592 ;$ d.f. $=4 ; \mathrm{p}<0.05$ & $\mathrm{X} 2=218.88 ;$ d.f. $=2 ; \mathrm{p}<0.05$ \\
\hline
\end{tabular}

*Mean age $=35.6$ yrs with SD of 15.66 yrs, mean age of male $=35.3 \mathrm{yrs}$, mean age of female $=35.4 \mathrm{yrs}$
Table on demographic profile of the RTA cases shows that majority cases were Hindu (90.5\%), from urban areas $(72 \%)$ and were married $(65.9 \%)$. The males were more in Muslims (95\%), rural areas $(97.5 \%)$ and in married $(91.1 \%)$ RTA cases, however this sex difference was found significant regarding place of residence only (table 2 ).

Table- 2: Demographic profile of RTA cases

\begin{tabular}{|c|c|c|c|}
\hline \multirow[t]{2}{*}{ Demographic profile } & \multicolumn{2}{|c|}{$\begin{array}{c}\text { Road traffic accident } \\
\text { cases }\end{array}$} & \multirow[t]{2}{*}{$\begin{array}{c}\text { Total } \\
(\mathrm{N}=425)\end{array}$} \\
\hline & $\begin{array}{l}\text { Male } \\
(\mathrm{N}=381)\end{array}$ & $\begin{array}{l}\text { Female } \\
(\mathrm{N}=44)\end{array}$ & \\
\hline \multicolumn{4}{|l|}{ Religion } \\
\hline Hindu & $343(89.1)$ & $42(10.9)$ & $385(90.6)$ \\
\hline Muslim & $38(95)$ & $2(5)$ & $40(9.4)$ \\
\hline \multicolumn{4}{|l|}{$\mathrm{X} 2=1.363 ;$ d.f. $=1 ; \mathrm{p}>0.05$} \\
\hline \multicolumn{4}{|l|}{ Residence } \\
\hline Urban & $265(86.6)$ & $41(13.4)$ & $306(72)$ \\
\hline Rural & $116(97.5)$ & $3(2.5)$ & $119(28)$ \\
\hline \multicolumn{4}{|l|}{$\mathrm{X} 2=10.923 ;$ d.f. $=1 ; \mathrm{p}<0.05$} \\
\hline \multicolumn{4}{|l|}{ Marital status } \\
\hline Married & $255(91.1)$ & $25(8.9)$ & $280(65.9)$ \\
\hline Unmarried & $111(88.1)$ & $15(11.9)$ & $126(29.6)$ \\
\hline $\begin{array}{l}\text { Widow/Widower/Divorced/ } \\
\text { Separated }\end{array}$ & $15(78.9)$ & $4(21.1)$ & $19(4.5)$ \\
\hline \multicolumn{4}{|l|}{$\mathrm{X} 2=3.283 ;$ d.f. $=2 ; \mathrm{p}>0.05$} \\
\hline Total & 381 & 44 & 425 \\
\hline
\end{tabular}

Table- 3: Biosocial characteristics of RTA cases

\begin{tabular}{|l|l|l|}
\hline \multicolumn{2}{|l|}{ Socioeconomic status } & \multicolumn{2}{l|}{ Road traffic accident cases } \\
\cline { 2 - 3 } \multicolumn{2}{|l|}{ Number ( $\mathrm{n})$} & Percent (\%) \\
\hline Educational Status & 266 & 62.6 \\
\hline Illiterate & 44 & 10.4 \\
\hline Primary School & 39 & 9.2 \\
\hline Middle School & 39 & 9.2 \\
\hline High School & 25 & 5.8 \\
\hline Intermediate & 12 & 2.8 \\
\hline Graduate or Post-graduate / Professional & \multicolumn{2}{|l|}{} \\
\hline Occupation & 11 & 2.7 \\
\hline Unemployed & 24 & 5.6 \\
\hline Students & 180 & 42.4 \\
\hline Laborer & 38 & 8.9 \\
\hline Housewife & 39 & 9.2 \\
\hline Shoe maker/ bangle maker/electrician & 90 & 21.2 \\
\hline Driver & 90 & 7.7 \\
\hline Clerical/shop owner/farmer & 33 & 2.3 \\
\hline Semi-professional /Professional & 10 & 11.4 \\
\hline Socio-economic class* & \multicolumn{2}{|l}{} \\
\hline Upper(I)/ Upper Middle(II) & 6 & 82.8 \\
\hline Lower Middle(III) & 48 & \multicolumn{2}{|l}{} \\
\hline Upper Lower(IV) & 352 & 11.3 \\
\hline
\end{tabular}




\begin{tabular}{|l|l|l|}
\hline Lower $(\mathrm{V})$ & 19 & 4.5 \\
\hline Total & 425 & 100 \\
\hline
\end{tabular}

\section{*Modified Kuppuswami Scale-2012}

Out of total 425 RTA cases, $62.6 \%$ were illiterate, whereas only $8.6 \%$ were educated above high school and around $10 \%$ each were educated up to primary and middle classes respectively. It is also clear seen from the table that maximum $(42.3 \%)$ were laborers by occupation followed by $30.4 \%$ as skilled workers (driver/ artesian/electrician). 8.9\% were housewives and $2.7 \%$ were unemployed. According to modified Kuppuswami scale (2012), it was seen that majority $(82.8 \%)$ of the cases belonged to upper- lower social class while another $11.2 \%$ belonged to lower- middle. Very few $(1.4 \%)$ belonged to social class I \&II (table 3).

Table $4 \& 5$ shows the distribution of RTA cases as type of road users and as per their age and sex. It was found that two wheelers users were most common cases followed by pedestrians (38.4\%\&37.6\% respectively), while users of non motorized vehicles were least common suffers $(7.3 \%)$.When type of road users were studied according to age group, it was observed that in all age group except 16-30 yrs, pedestrians were most commonly involved. In $<15$ yrs age group, 69.3\% pedestrians were injured, followed by two wheelers (19.2\%). Among 16-30 yrs age group, two wheeler users were involved in $52.4 \%$ instances, while pedestrians were involved in $27.1 \%$ instances. In 31-45 yrs and $46-60$ yrs age groups, a similar trend was observed, pedestrians $(42.8 \% \quad \& 37.2 \%$ respectively) being most commonly involved followed by two wheelers $35.4 \% \quad \& 32.1 \%$ respectively). Among $>60$ yrs most commonly involved road users were also pedestrians (48.8\%) followed by NMV $(26.8 \%)$. Statistically there is significant association between type of road users and the age group (table 4).

Table-4: Distribution of RTA cases according to type of road users and age

\begin{tabular}{|l|l|l|l|l|l|l|}
\hline \multirow{2}{*}{ Road Users } & \multicolumn{5}{|c|}{ Age Group (yrs) } & \multirow{2}{*}{ Total } \\
\cline { 2 - 6 } & 15 & $16-30$ & $31-45$ & $46-60$ & $>60$ & \\
\hline Pedestrians & $18(69.3)$ & $46(27.1)$ & $47(42.8)$ & $29(37.2)$ & $20(48.8)$ & $160(37.6)$ \\
\hline Two wheelers & $5(19.2)$ & $89(52.4)$ & $39(35.4)$ & $25(32.1)$ & $5(12.2)$ & $163(38.4)$ \\
\hline LMV/HMV & $1(3.9)$ & $28(16.4)$ & $22(20.0)$ & $15(19.2)$ & $5(12.2)$ & $71(16.7)$ \\
\hline $\begin{array}{l}\text { Non } \\
\text { motorized* }\end{array}$ & $2(7.6)$ & $7(4.1)$ & $2(1.8)$ & $9(11.5)$ & $11(26.8)$ & $31(7.3)$ \\
\hline Total & $\begin{array}{l}26 \\
(100.0)\end{array}$ & $\begin{array}{l}170 \\
(100.0)\end{array}$ & $\begin{array}{l}110 \\
(100.0)\end{array}$ & $\begin{array}{l}78 \\
(100.0)\end{array}$ & $\begin{array}{l}41 \\
(100.0)\end{array}$ & $\begin{array}{l}425 \\
(100.0)\end{array}$ \\
\hline X2=67.937; d.f. =12; $\mathrm{p}<0.05$ & & & \\
\hline
\end{tabular}

*Non motorized (pedal cyclist, tricycle occupant/ rider)

Table-5: Distribution of RTA cases according to type of road users and sex

\begin{tabular}{|l|l|l|l|l|}
\hline \multirow{2}{*}{ Type of road users } & \multicolumn{3}{|c|}{ Road traffic accident cases } & \multirow{2}{*}{ Z value } \\
\cline { 2 - 4 } & Male & Female & Total & \\
\hline Pedestrians & $133(34.9)$ & $27(61.4)$ & $160(37.6)$ & 3.428 \\
\hline Two wheelers & $152(39.9)$ & $11(25.0)$ & $163(38.3)$ & 2.131 \\
\hline LMV/HMV & $65(17.1)$ & $6(13.6)$ & $71(16.7)$ & 0.636 \\
\hline Non motorized* & $31(8.1)$ & $0(0.0)$ & $31(7.3)$ & 5.827 \\
\hline Total & $381(100.0)$ & $44(100.0)$ & $425(100.0)$ & \\
\hline X2=13.472; d.f. $=3 ; p<0.05$ & & & \\
\hline
\end{tabular}

The table 5 depicts that among males most commonly involved type of road users were two wheelers $(39.9 \%)$ followed by pedestrians $(34.9 \%)$. On the contrary among females, most commonly involved were pedestrians $(61.4 \%)$ followed by two wheelers $(25.0 \%)$. Statistically there is significant difference between type of road users among male \& female sex. On going in more details of type of road users, figure -1 depicts that maximum (37.6\%) accident cases were pedestrians, $19.6 \%$ were two wheeler drivers, $18.6 \%$ were two wheeler pillions while $9.6 \%$ were three wheeler driver or occupants. Pedal cyclists involved in the accident were $7.5 \%$ and $4.5 \%$ were car/ van drivers or occupants. Only $1.2 \%$ was tricycle occupant/rider. It was found that motorized two wheeler (33.2\%) was the most common object followed by LMV\& HMV ( $22.8 \%$ \& $15.3 \%$ respectively). In $17.9 \%$ cases non motorized vehicle was the hitting objects (table 5).

\section{Discussion}

The present study was conducted to know the sociodemographic profile of RTA cases. According to WHO report on "Global status report on road safety 2013 it was found that road traffic accidents are the leading cause of death among young people aged 15-29 yrs and about 46\% those dying are " vulnerable road users"[1]. In the present study it was found that $89.6 \%$ of the cases were males. Similarly Jha Nilambar et.al \& Kumar Srinivasa P.V. et.al also found that males were predominantly involved [5,6]. It was also found that maximum cases were in the age group of $16-30$ years $(40.0 \%)$, followed by $31-45$ yrs $(25.8 \%)$. Similar trend was also observed by Mishra B et al [7] \& Khare et.al [8] who reported that the maximum cases were in the age group of $15-30$ years $(38.3 \%$ $\& 50 \%$ respectively) followed by $31-45 y$ rs age group. 
Patil S S et al [9] also observed that the maximum $(29.4 \%)$ cases were between $20-29$ years of age. Among males $16-30$ years age group (42.3\%) was the most commonly affected, while among females the most common age group was 46-60 years (34.1\%). Gudadinn M. R [10] found that the maximum (30.9\%) of cases were in the age group of 20-30 yrs both in males and females as compared to our study. Sharma Deepak et.al [11] found that in males the most common age group involved was $21-30$ years (31.8\%) whereas in case of females the highest number of cases was seen in the age group of $31-40$ years $(21.9 \%)$. This sex difference may obviously be due to the fact that males tend to travel more for work related and other purposes as compared to females. Majority $(72.0 \%)$ were urban dwellers, while $28.0 \%$ were from rural areas. However Mishra B et al [7] and Viren Kaul et.al [12] found that majority of the cases in their studies were from rural areas as compared to urban areas. This variation might be due to the location and catchment area of the hospital as the present study has been conducted in a tertiary level hospital located in the heart of the city. In the present study, $65.8 \%$ were married. Similarly Singh Abhishek et.al [13] \& Singh R K et.al [14] found that most of the cases who suffered from accidents were married. The apparent occurrence of road accidents more among married may be due to the other determining factors for RTA like age rather than marital status.

In the present study most $(62.6 \%)$ of the cases were illiterate, while $28.8 \%$ cases had education up to high school level. This finding is in corroboration with the findings of Singh RK et.al [14] who also reported that maximum of the cases were illiterate but the proportion is lower $(24.5 \%)$ than the present study followed by $16.3 \%$ were educated up to primary and middle education each. In contrast to the present study, Kumar Srinivasan P.V. et.al [6] found that $39.3 \%$ were graduates, followed by $31.1 \%$ with intermediate education. Unskilled laborers $(42.4 \%)$ formed the largest group in the present study while another $21.2 \%$ cases were drivers. Similar occupation profile was noted by Bayan Pankaj et.al [15] \& Singh Abhishek et.al [13] in their study. Because in the present study most of the cases were illiterate and laborers majority of the cases $(82.8 \%)$ belonged to upper- lower class. Only $1.4 \%$ belonged to upper/ upper middle classes. These findings are consistent with the findings of Urfi et.al [16] where maximum cases were from upper lower class.
However, upper middle class (63.9\%) was noted as the largest group by Kumar Srinivasa P.V. et.al [6].

In the present study, $45.1 \%$ of the cases were pedestrians or pedal cyclists, while $38.2 \%$ of the victims were two wheeler drivers/ pillion. A similar trend was documented by Kiran E. Ravi et.al [17] who found that majority $(60.2 \%)$ of the cases were pedestrians, followed by two wheelers (23.6\%). Patil Supriya Satish et.al [9] \& Khare Neeraj et.al [8] mentioned that two wheeler occupants constituted the maximum number of RTA cases (49.7\% \& 73\% respectively), followed by pedestrians $(13.4 \%$ \& $10 \%$ respectively). The difference might be due to the fact that the roads lack a separate section or footpath for pedal cyclists or pedestrians, respectively. Thus there are a substantial proportion of RTA victims who were injured while walking or riding pedal cycles. Maximum (33.2\%) cases were hit by two wheelers, followed by those who were hit by LMV (22.8\%). A little less than $20 \%$ of the cases were not hit by any motorized vehicle. Similarly Patil S.S et.al [9] \& Kumar Verma Pramod et.al [18] found that maximums $(31.9 \%)$ were hit by two-wheelers (31.9\% \& 24.5\% respectively), followed by LMV (29.8\% \&15\% respectively). But on the contrary Chanchlani Roshan et.al [19] found that $71.4 \%$ of victims were hit by four wheelers.

\section{Conclusion}

Majority of the RTA cases are in the economically productive age group and are married, hence their hospitalization or disability places a huge economic burden on the family.

\section{Reference}

01 . Global status report on road safety 2013.

Available at: [Article] [Crossref]

02. National Crime Records Bureau- accidental deaths \& suicides in India.

Available at: [Article] [Crossref]

03. World report \& road traffic injuries prevention. 2004. Available at

[Article] [Crossref]

04. Gururaj G. Road traffic deaths, injuries and disabilities in India- current scenario. Natl Med J India. 2008 Jan-Feb;21(1)14-20.

[Crossref] 
05. Jha N, Srinivasa DK, Roy G, Jagdish S. Injury pattern among road traffic accident cases- a study from south India. Indian Journal of Community Medicine. 2003;28(2)85-90.

[Crossref]

06. Srinivasa PK, Srinivasan K. To study the socio demographic profile of road traffic accident victims in district hospital, Karimnagar. Int J Res Dev Health. 2013;1(3)136-40.

[Crossref]

07. Mishra B, Sinha Mishra ND, Sukhla S, Sinha A. Epidemiological study of road traffic accident cases from Western Nepal. Indian J Community Med. 2010 Jan;35(1)115-21.

doi: $10.4103 / 0970-0218.62568$ [Crossref]

08. Khare N, Gupta SK, Varshney A, Athavale AV. Epidemiological study of road traffic accident cases attending tertiary hospital in Bhopal Madhya Pradesh. Indian journal of community medicine. 2012;3(3)395-399.

[Crossref]

09. Patil SS, Kakade R, Durgawale P, Kakade S. Pattern of road traffic injuries- a study from Western maharashtra. Indian J Community Med. 2008 Jan;33(1)56-7.

doi: 10.4103/0970-0218.39248 [Crossref]

10. Gudadinn MR. A study of road traffic accidents case admitted in BLDEA. Shri BM patil medical college and hospital and research center, Bijapur. 2007.

[Crossref]

11. Sharma D, Singh US, Mukherjee S. A study on road traffic accidents in Anand-Gujarat. Healthline. 2011;2(2)12-15.

[Crossref]

12. VirenKaul, Dattatreya D Bant, ND Bendigeri, Geeta Bhatija. A brief medico-sociodemographic profile of non-fatal road traffic accident cases admitted to Karnataka Institute of Medical Sciences. Scholar's research journal. 2011;1(1)32-36.

[Crossref]

13. Singh A, Bhardwaj A, Pathak R, Ahluwalia SK. An epidemiological study of road traffic accident cases at a tertiary care hospital in rural Haryana. Indian Journal of Community Health. 2011;23(2)20-24.

[Crossref]
14. Singh RK, Gupta K, Kumar A, Singh GK, Singh A, Kumar $S$. Elucidation of risk factors in survivors of road traffic accidents in north India. Hard Tissue. $2013 ; 14 ; 2(1) 1$. [Crossref]

15. Bayan P, Bhawalkar JS, Jadhav SL, Banerjee A. Profile of non-fatal injuries due to road traffic accidents from a industrial town in India. Int J Crit Illn Inj Sci. 2013 Jan;3(1)8-11. doi: $10.4103 / 2229-5151.109409$ [Crossref]

16. Urfi, Ali Amir, Salman Khalil. Socio-Demographic Profile and Severity of Head Injury among Victims of Road Traffic Accidents in Aligarh. International global research analysis. 2013;2(4)219-220.

[Crossref]

17. Kiran ER, Saralaya KM, Vijaya K. Prospective study on road traffic accidents. JPAFMAT. 2004;4;12-16.

[Crossref]

18. Verma PK, Tewari KN. Epidemiology of road traffic injuries in Delhi. Regional Health Forum. 2004;8(1)6-14.

[Crossref]

19. Chanchlani R, Mahawar PK, Sinha U. External injury pattern of road traffic accidents- An epidemiological study in a tertiary care setting, Bhopal. Journal of Evolution of Medical and Dental Sciences. 2013;32(2)6050-6055. [Crossref] 